\title{
Monopoly money
}

Strategies used by the pharmaceutical industry to alleviate the pain of patent expiration provide some valuable lessons for the biotechnology sector. . .and also some cautionary tales, says Alan Dove.

\section{Octogenarians at the gate}

On 25 April 2001, a coalition of consumer groups, spearheaded by a senior citizens' activist group called the Gray Panthers, filed a class-action lawsuit against BristolMyers Squibb (New York) for damages caused by anticompetitive business practices. Specifically, the Panthers argue that Bristol-Myers Squibb abused FDA patent-listing procedures to block pending generic competition against BuSpar (buspirone), an antianxiety drug, a scheme that they claim cost consumers $\$ 100$ million. Bristol-Myers Squibb denies the accusations. In another class-action suit filed in April, plaintiffs claim that Schering-Plough (Kenilworth, NJ) paid $\$ 90$ million to Upsher-Smith (Minneapolis, $\mathrm{MN}$ ) and ESI Lederle (Philadelphia, PA), a division of American Home Products, to keep generic versions of the potassium chloride supplement K-Dur 20 off the market. Schering, Upsher-Smith, and AHP have denied any wrongdoing ( $N a t$.

Biotechnol, 19, 497, 2001). These lawsuits are part of an emerging backlash against pharmaceutical companies' efforts to extend marketing exclusivity on profitable drugs, and biotechnology companies will be well advised to watch the outcome of such litigation and learn.

Alan D ove is a freelance writer working in Philadelphia, PA (alanwdove@earthlink.net).

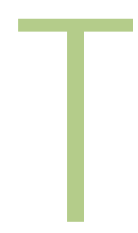

here is an old saying that the only two things guaranteed in life are death and taxes. Pharmaceutical and biotechnology companies can add another to the list- the expiration of patents. Twenty-five years ago, the biotechnology industry was tentatively emerging from the recesses of laboratories and began to start exploring the commercial potential of genetically modified organisms and recombinant proteins. Today, it is a rapidly maturing industry, with marketed products and considerable economic clout. But as it becomes more mature, the industry will also begin to suffer from new problems - the expiration of patent life covering some of its early products being just one. In this respect, pharmaceutical companies have developed increasingly sophisticated ways to protect their patents and profits, and some of these approaches will be broadly applicable to the biotechnology industry.

\section{The point of patents}

Patents were originally conceived in the $18^{\text {th }}$ century as a legal tool to encourage industrial innovation. To receive a patent, an invention must fulfill three criteria: it must be novel, useful, and not be obvious from work that had gone before. Patents can cover composition of matter (e.g., a new insecticide), methods of production (e.g., a way of making the insecticide), or devices (e.g., a sprayer to apply insecticides to crops). A patent rewards innovators by granting them a limited monopoly in the marketplace, during which competitors are prevented from selling their own versions of the product.

Although the basic principles are the same worldwide, patent protection was implemented differently in different countries. To establish uniformity, the General Agreement on Tariffs and Trade- replaced by the World Trade Organization (WTO) in 1995-drew up international standards for patents. Under theWTO's Trade-Related Aspects of Intellectual Property Rights (TRIPs) agreement, a patent must grant the inventor an exclusive market for the invention for at least 20 years from the date the application was filed. On paper at least, all 140 nations that are currently members of the WTO provide this level of patent protection, although its enforcement varies considerably.

In most industries, including agricultural and industrial biotechnology, a patent provides an effective $(5)$ monopoly al most immediately. However, in the pharmaceutical industry, getting a patented compound approved as a drug typically takes several years, during which time the patent clock is ticking. The US

Waxman-H atch Act of 1984 sought to remedy this problem by providing a compound with extended market exclusivity, but simultaneously encouraging generic competition once the patent expired. $M$ att vanHook, a spokesman for the Pharmaceutical Research and M anufacturers' Association (PhRM A; Washington, DC), says: "A typical drug has, once it gets on the market, only about 8.5 years of effective life left before its patent runs out. With the partial restoration added by Waxman- $\mathrm{H}$ atch...they get about 11.5 years."

A Waxman-H atch style "patent restoration term" for pharmaceuticals is not available in the European Union and Canada. H owever, theimplementation of a Waxman- $\mathrm{H}$ atch style ruling would have less impact on product sales for medicines than it does in the United States because of the tight price controls on prescription drugs in these regions. Canada is currently in the process of reviewing its patent laws in an effort to accommodate the products of biotechnology, and one of the issues being considered is a possible restoration-ofpatent term likeWaxman-Hatch. Richard Gold, an advisor to the Canadian Biotechnology Advisory Committee 
(CBAC) on intellectual property issues, explains: "We are considerably behind both the United States and Europe in terms of deciding what...is patentable and what is not. Canada hasn't yet decided whether plants and animals are patentable." The CBAC is soliciting public input on its draft report, expecting to submit its final recommendations to Parliament in late June.

\section{Patent proof}

Even with the implementation of a patentrestoration term, all drug patents eventually come to an end, and companies have become aggressive in their attempts to avoid the inevitable loss of profit. According to analysts, the absence of prescription-drug price controls, the presence of a robust generic-drug industry, and easy access to civil courts, have combined to make the United States the focus of most efforts to extend market exclusivity.

$M$ ichael Krensavage, a health care analyst for Raymond James and Associates ( N ew York), says that pharmaceutical companies "have been very creative" about protecting exclusivity for their blockbuster drugs. For example, in 1993, SmithK line Beecham (Philadelphia, PA) claimed that the American HomeProducts' (Madison, NJ) generic version of its ulcer drug Tagamet (cimetidine) infringed its patent because the pills were the same color. "The way the law works, it can take up to 30 months (the FDA-required halt period) to settle these things in court," says Krensavage. The generic drug cannot be sold whilethe case is in court, and the original manufacturer's monopoly is therefore extended. Krensavage explains: "M illions of dollarsa day in sales adds up to a lot of attorneys' fees, so while your efforts don't have to be valid, you can stall for a while."

Lawsuits do not even have to go to court in order to extend a brand-name monopoly. In a practice that consumer groups claim is increasingly prevalent, a brand-name manufacturer will sue the generic company, and the two companies then reach a "settlement" in which the brand-name company pays its competitor to stay out of themarket. Drug manufacturers deny accusations that these arrangements violate antitrust laws - and indeed there is a fundamental conflict between patent protection and the spirit of freetrade- but insurers and consumer groups alike say that such "settlements" smack of collusion (see "O ctogenerians at thegate").

\section{New delivery routes}

A more sustainable approach for small-molecule drug developers is to formulate brand- ed drugs into different (or novel) drug delivery systems. Companies can, for example, create a version of a brand-name drug that can be given just once a day, because the patent on the new system will enjoy an additional 20 years of market exclusivity. For example, Pfizer (New York) recently introduced Glucotrol $X L$, a once-daily version of its popular diabetes drug, Glucotrol (glipizide). The new product constitutes a novel formulation of the original branded drug, and the company had to carry out further clinical trials to get USFood and Drug Administration (FDA) approval. However, Don Ellis, an analyst at Thomas Weisel
H owever, a specific technique, such as a surgical procedure or, possibly, the delivery of a particular geneto a particular tissue, cannot be patented in the European Union or Canada. For genetherapy companies, for example, CBAC's Gold says: "The gene therapy or the vector can be patented, but the injection into the body is not patentable. Usually it won't make a big difference, but you can imagine that at some point this could becomean issue."

Industry experts agree that some biotechnology products- such as DNA microarrays- are still too new to predict the impact of the expiration of their patents. If the

\section{Developing new delivery techniques to extend marketing exclusivity-so-called evergreening - may eventually become more difficult for biotechnology companies in Europe and Canada, neither of which allows patents on "medical treatments and surgical methods."}

Partners (New York), says: "There's very little risk [ of carrying out such trials], because all the toxicology is well known to the FDA." Generic versions of the original drug may be manufactured and sold, but thenew branded formulation has the distinct competitive marketing advantages of both reputation and a longer-lasting formulation.

In addition to longer-lasting formulations, drug makers can try to deliver the drug in more innovative ways, such as transdermal patches or implanted capsules Biotechnology companies are developing needle-free ways to deliver drugs through theskin (e.g., PowderJect; Oxford, UK) or lungs (e.g., Inhale; San Carlos, CA). Pharmaceutical companies are keen to collaborate with such companies. Indeed, one motivation for Johnson \& Johnson's ( New Brunswick, $N$ J) recent high-profile $\$ 10$ billion acquisition of drug-delivery pioneer Alza (M ountain View, CA) was the new delivery systems that it intends to use to rejuvenate its ageing drugs pipeline ( $\mathrm{N}$ at. Biotechnol. 19, 398, 2001).

Developing new delivery techniques to extend marketing exclusivity-so-called evergreening - may eventually become more difficult for biotechnology companies in Europe and Canada, neither of which allows patents on "medical treatments and surgical methods." The prohibition is subtle: a drug can be patented under "unique composition of matter," and a device that delivers the drug can be patented as a "device".
DNA chip industry follows the pattern of the pharmaceutical industry, chip manufacturers might try to block generic competition in similar ways. Alternatively, the DNA chip business might follow the pattern of the computer chip industry, in which the rapid pace of innovation has often rendered patent expiration moot.

\section{The trouble with proteins}

Under current regulations, recombinant protein therapeutics are highly resistant to generic competition, primarily because of the regulatory structure of drug-approval agencies, such as the US FDA. A therapeutic small molecule is classified as a "drug", but proteins (and vaccines) are considered "biologics" and are governed by different rules.

A company that wishes to produce a generic small molecule after the patent has expired needs only to demonstrate that it is chemically and biologically equivalent to the brand-name product- tests that are far less expensive to conduct than full-scale clinical trials de novo. However, a biologic generic (or biogeneric) manufacturer has to carry out a completely new set of clinical trials to bring the generic product to market, making generic proteins a less favorable business proposition ( $\mathrm{N}$ at. Biotechnol. 19, 117, 2001).

N onetheless, makers of protein therapeutics are avidly pursuing patentable improve ments on existing drugs. Eli Lilly 
(Indianapolis, IN), for example, was able to get a new orphan drug approval for its human growth hormoneby developing an improved process for manufacturing the protein. Amgen (Thousand Oaks, CA) has begun phase 3 clinical trials of Aranesp, a version of recombinant human erythropoietin that will last longer in the bloodstream. Amgen's original erythropoietin patent expires in 2004.

Other biotech companies would also be wise not to rest on their laurels. Pedro de Noronha Pissarra, president of Biotecnol (Porto Salvo, Portugal), explains: “One should not forget that biotechnology generics are al ready being marketed outside the European Union and United States, and to my knowledge they are well accepted." Pissarra suggests that Asia and South America could be ideal locations for marketing biogenerics, because full-scale clinical trials of biogenerics are not required before marketing. M eanwhile, companies like C angene (Winnipeg, M B, Canada) are al ready devel oping biogenerics for the North American and European markets.

\section{Agricultural agro}

The situation for agricultural biotechnology is less clear, in that the most successful products to date- Bt transgenic crop strains and herbicide-tolerant plants-still have more than 10 years of patent protection remain- numbers: most of the patents in the field are broad, and owned by a small set of large companies, making it unlikely that a generic manufacturer could compete successfully.

Still, as future patent rules evolve, biotechnology companies, liketheir pharmaceutical

\section{The most successful products to date- $B t$ transgenic crop strains and herbicide-tolerant plants-still have more than 10 years of patent protection remaining.}

ing. $M$ ark Buckingham, a spokesman for M onsanto (St. Louis, M O), says that the company intends to pursue the only surefire strategy for protecting its lead: "I t is very difficult to tell in agricultural biotechnology what the state of the art technology may be...more than ten years' time. It's our intention to develop that technology that will be state of the art, rather than to focus on extending our existing patents."

Besides innovation, agricultural biotech companies also enjoy strength in a lack of counterparts, will have to continue to swallow the bitter pill of patent expiration. However, the availability of genomic sequence information and advances in bioinformatics are also expected to accelerate competition for biotechnology drugs, possibly driving older products into obsolescence before their patents have expired. "Quite aside from any generic competition. . .this is a time of scientific ferment, so you've got intense competition among innovators," says PhRM A's vanH ook. 